\title{
Study on the Thermal Treatment of Nano-Ag/TiO 2 Thin Film
}

\author{
Peng Bing, Wang Jia, Chai Li-yuan, Wang Yun-yan, and Mao Ai-li \\ School of Metallurgical Science and Engineering, Central South University, Changsha 410083, China \\ Correspondence should be addressed to Chai Li-yuan, liyuanchai@mail.csu.edu.cn \\ Received 6 April 2011; Accepted 3 May 2011 \\ Academic Editor: S. K. Mohapatra
}

Copyright ( $) 2011$ Peng Bing et al. This is an open access article distributed under the Creative Commons Attribution License, which permits unrestricted use, distribution, and reproduction in any medium, provided the original work is properly cited.

The photocatalytic degradation rates of methyl orange and antibacterial properties of nano-Ag/ $/ \mathrm{TiO}_{2}$ thin film on ceramics were investigated in this study. XRD was used to detect the structure of film to clarify the impacts on the rates and properties. The effect of film layers, heating temperature, heating time, and embedding of $\mathrm{Ag}^{+}$on the degradation rates and antibacterial properties were ascertained. The nano- $\mathrm{Ag} / \mathrm{TiO}_{2}$ film of 3 layers with $\mathrm{AgNO}_{3} 3 \%$ embedded and treated at $350^{\circ} \mathrm{C}$ for $2 \mathrm{~h}$ would exhibit good performance.

\section{Introduction}

Because of its nanoeffect, high activity, and characteristic [1] of the reuse in the immobile catalyzer application, the nano- $\mathrm{TiO}_{2}$ thin film has great value in both theory study and application [2-4]. The ceramics with nano- $\mathrm{TiO}_{2}$ thin film immobilized on glaze is a kind of new hightech materials which is becoming the hotspot of high-tech product with a nice foreground [5]. Steady nano- $\mathrm{TiO}_{2}$ watersol was prepared in the study done before [6], and then put ceramics into the water-sol to load $\mathrm{TiO}_{2}$ humid film, after that conducted thermal treatment. The photocatalytic and antibacterial performances of the film were dependent on the thermal treatment conditions.

The photocatalytic degradation rate of methyl orange and antibacterial property of nano- $\mathrm{Ag} / \mathrm{TiO}_{2} 2$ thin film on ceramics were used as main index in addition to XRD analysis in this investigation. The effects of film layers, heating temperature, heating time, and embedding of $\mathrm{Ag}^{+}$ on the degradation ratio and antibacterial property were studied.

\section{Experimental}

2.1. Preparation of $\mathrm{TiO}_{2}$ Water-Sol. According to the literature [6], 5\% nitric acid or $3 \%$ hydrochloric acid were used to peptize 0.1 or $0.2 \mathrm{~mol} / \mathrm{L} \mathrm{H}_{4} \mathrm{TiO}_{4}$ at $\mathrm{pH}=1.4$, then the mixture was agitated in water bath at $80^{\circ} \mathrm{C}$ until it became translucent sol. The following reactions [7] took place in the procedure:

$$
\begin{gathered}
\mathrm{TiO}(\mathrm{OH})_{2} \downarrow+\mathrm{H}^{+} \longrightarrow \mathrm{TiO}(\mathrm{OH})^{+}+\mathrm{H}_{2} \mathrm{O}_{n}, \\
\mathrm{TiO}(\mathrm{OH})^{+}+\mathrm{H}_{2} \mathrm{O}_{n}+\mathrm{H}^{+} \longrightarrow \mathrm{TiO}^{2+}+2 \mathrm{H}_{2} \mathrm{O}
\end{gathered}
$$

2.2. Preparation of $\mathrm{TiO}_{2}$ Thin Film Immobilized on Ceramics Glaze. The ceramics were cut into $50 \mathrm{~mm} \times 50 \mathrm{~mm}$ pieces and washed with deionized water, $5 \% \mathrm{NaOH}$ solution, alcohol and distilled water, then dried at room temperature. The treated ceramics were put into the $\mathrm{TiO}_{2}$ water-sol to load $\mathrm{TiO}_{2}$ humid film. After that, they would be dried in an oven at $100^{\circ} \mathrm{C}$. By repeating these operations, the films with requisite thickness were prepared. Finally they were heated in a Muffle Furnace from $100^{\circ} \mathrm{C}$ to appointed temperature at the rate of $4 \sim 5^{\circ} \mathrm{C}$ per min for $2 \mathrm{~h}$.

\subsection{Measurements}

(1) Photocatalytic Degradation Performance. U-2010 ultraviolet-visible spectralphotometer made in Japan was used to test absorbance of methyl orange at $465 \mathrm{~nm}$ wavelength. The methyl orange and a piece of ceramics were put into a glass dish with a ZF-2 ultraviolet lamp (made in shanghai) 
TABLE 1: Antibacterial property of the film embedded different $\mathrm{Ag}^{+}$.

\begin{tabular}{lccc}
\hline & Blank & $1 \% \mathrm{AgNO}_{3}$ & $1 \% \mathrm{AgCl}$ \\
\hline Antibacterial ratio (\%) & 31 & 99 & 51.5 \\
\hline
\end{tabular}

TABle 2: Antibacterial property of the film embedded different amount of $\mathrm{Ag}^{+}$.

\begin{tabular}{lccccc}
\hline Ag amount $\left(\mathrm{AgNO}_{3}\right)$ & $0 \%$ & $1 \%$ & $3 \%$ & $5 \%$ & $7 \%$ \\
\hline Antibacterial ratio (\%) & 25 & 81 & 92.5 & 95.5 & 96 \\
\hline
\end{tabular}

at $253.6 \mathrm{~nm}$ wavelength lighting above. the degradation rate calculated in the following way [8].

$$
\text { Degradation rate }=\frac{A_{0}-A_{t}}{A_{0}} \times 100 \%
$$

(2) Antibacterial Performance. According to the literature [9], the antibacterial rates were tested by the method according to Japanese standards which was used by TOTO Co. and INAX Co. for testing antibacterial efficacy of antibacterial materials.

(3) X-Ray Diffraction Analysis. Rigaku D/max2550VB+ Xray diffraction analyzer made in Japan was used to observe the crystal structure of $\mathrm{TiO}_{2}$ thin film after heated at different temperature [10].

\section{Result and Discussion}

3.1. Effect of Ag Embedding on the photocatalytic and Antibacterial Performance. According to Section 2.1, 5\% nitric acid and $3 \%$ hydrochloric acid were used, respectively, to peptize $0.1 \mathrm{~mol} / \mathrm{L} \mathrm{H}_{4} \mathrm{TiO}_{4}$ at $\mathrm{pH}=1.4$, then the mixture was added with some silver nitrate (account for $1 \%$ weight of $\mathrm{Ti}$ ) and stired in water bath at $80^{\circ} \mathrm{C}$ until it became translucent sol. Then 2 types of ceramics with nano- $\mathrm{Ag} / \mathrm{TiO}_{2}$ thin film immobilized on glaze were prepared after 3 layers of humid film were loaded and treated at $550^{\circ} \mathrm{C}$ for $2 \mathrm{~h}$ according to Section 2.2.

Figure 1 indicates that $\mathrm{Ag}^{+}$improves the degradation rate. The reason is that $\mathrm{Ag}$ could restrain recombination of cavity and electron and improve photocatalytic performance of the film. Besides that, degradation rate of the film embedded $\mathrm{AgNO}_{3}$ is higher than the one embedded $\mathrm{AgCl}$. It is because that grain size of $\mathrm{TiO}_{2}$ in film prepared by $\mathrm{HNO}_{3}$ was also smaller than that prepared by $\mathrm{HCl}$ [6].

Table 1 indicates that antibacterial rate of the film embedding $\mathrm{AgNO}_{3}$ is higher than the one embedding $\mathrm{AgCl}$. There may be 2 reasons: first, the fomer actually has two types of $\mathrm{Ag}, \mathrm{Ag}_{2} \mathrm{SO}_{4}$ and $\mathrm{AgNO}_{3}$, either of which has higher solubility constant than $\mathrm{AgCl}$. So that there would be more Ag dissolving into bacterium solution, which could lead to higher antibacterial rate; Second, it is easier for $\mathrm{AgCl}$ to turn into elementary substance or silver oxide under light either of which has lower solubility constant than $\mathrm{AgCl}$ itself.

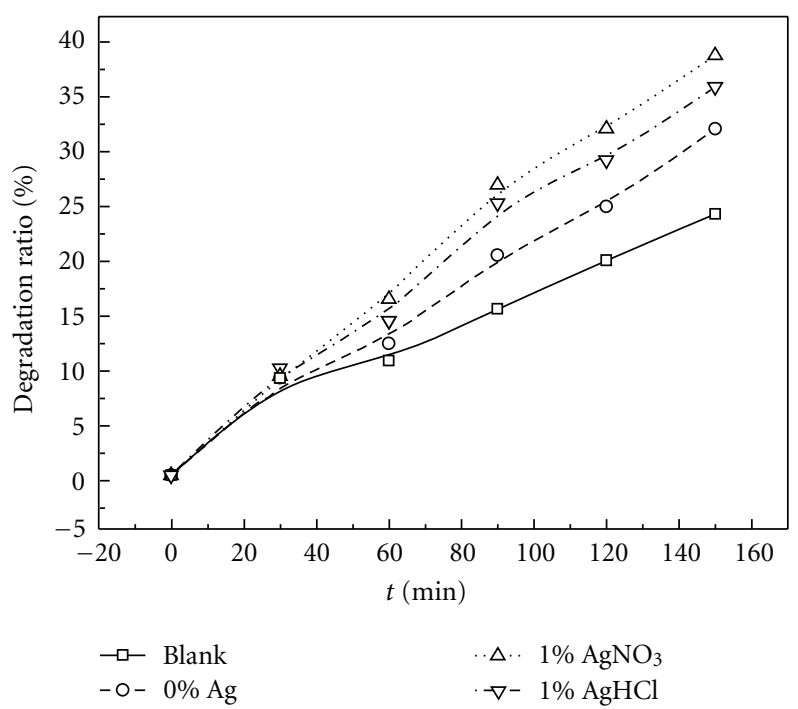

Figure 1: The film embedded different $\mathrm{Ag}^{+}$to the photocatalytic degradation ratio of methyl orange.

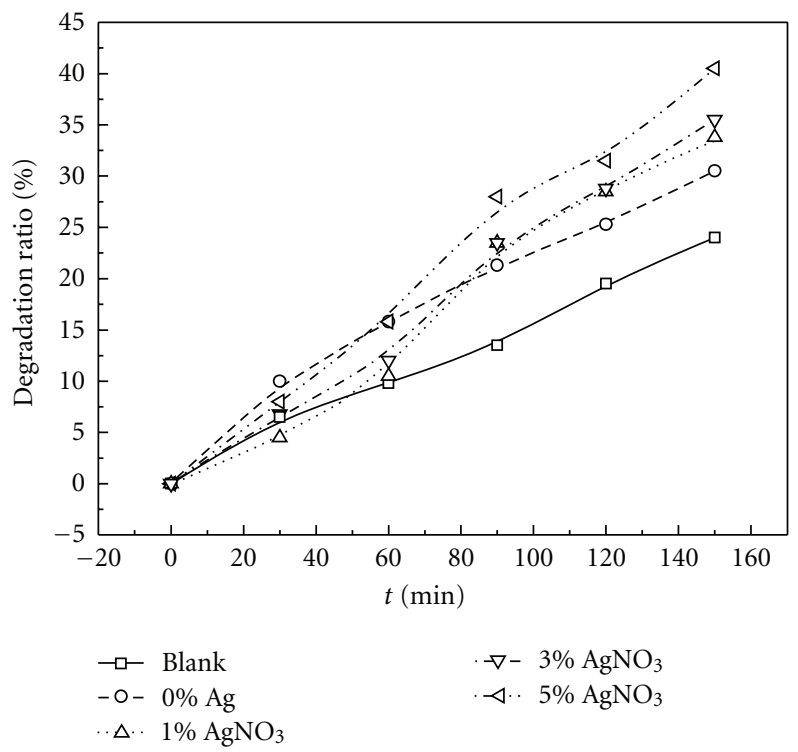

Figure 2: The film embedded different amount of $\mathrm{Ag}^{+}$to the photocatalytic degradation ratio of methyl orange.

According to the method stated at the beginning, but the amount of embedding Ag was change, the films with 1\%, 3\%, $5 \% \mathrm{AgNO}_{3}$ were prepared.

Figure 2 indicates that the film's photocatalytic performance is improved with the increasing of embedding Ag amount.

Table 2 indicates that the film's antibacterial rate is improved with the increasing of embedding Ag amount. The increasing of embedding Ag amount means that there would be more $\mathrm{Ag}^{+}$dissolving into bacterium solution. Beside that, although the amount of Ag embedding on film increased from $3 \%$ to $5 \%, 7 \%$, the antibacterial rate was not obviously improved, it is because that the concentration of $\mathrm{Ag}$ in 


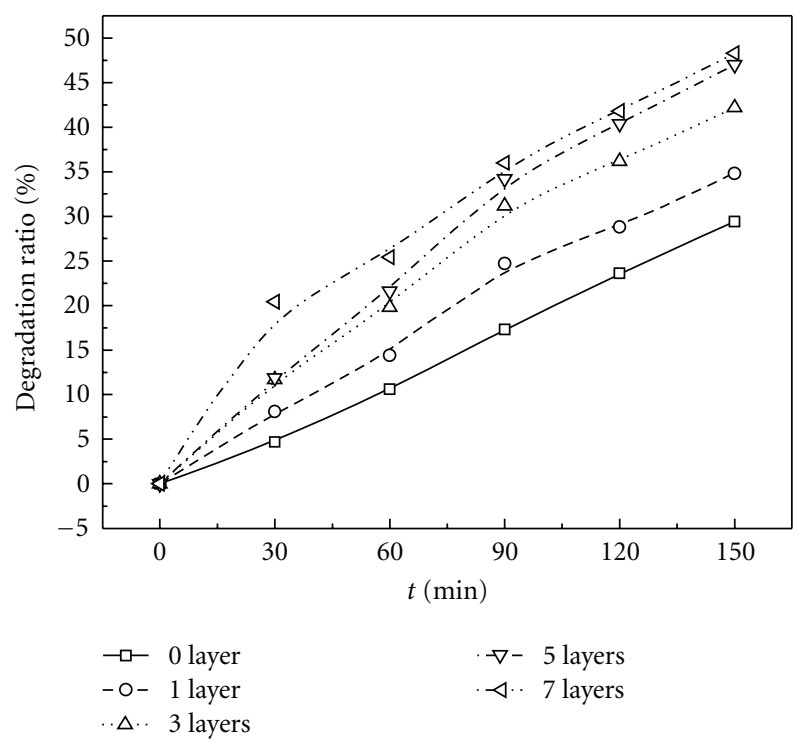

(a)

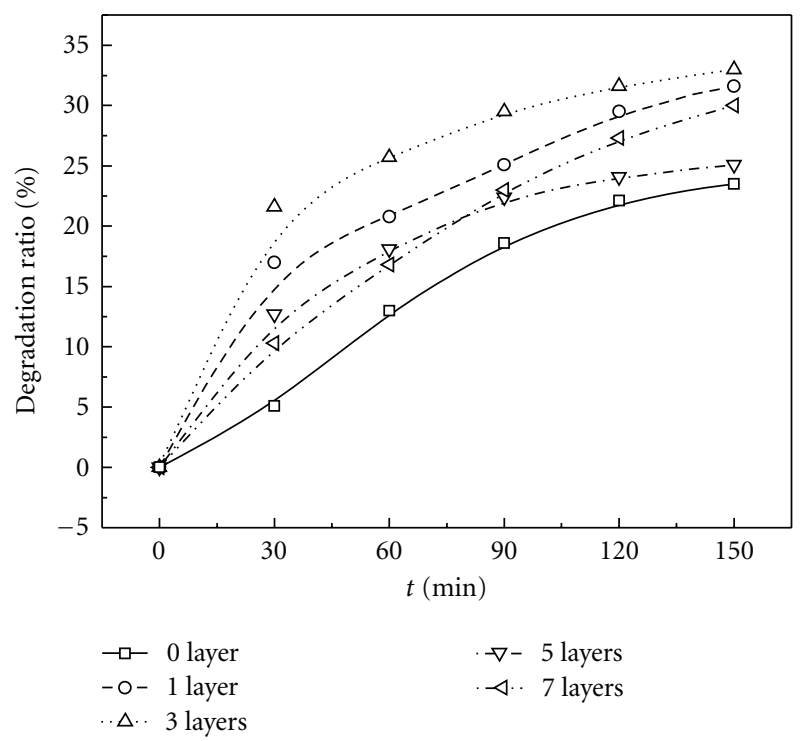

(b)

Figure 3: The different film layers to the photocatalytic degradation ratio of methyl orange ((a) $0.1 \mathrm{~mol} / \mathrm{L} \mathrm{sol}$; (b) $0.2 \mathrm{~mol} / \mathrm{L} \mathrm{sol}$ ).

the film dissolving into bacterium solution tends to be a constant.

\subsection{Effect of Thickness on the Photocatalytic and Antibacterial} Performance. According to Section 2.1, 5\% nitric acid was used to peptize $0.1 \mathrm{~mol} / \mathrm{L}$ and $0.2 \mathrm{~mol} / \mathrm{L} \mathrm{H}_{4} \mathrm{TiO}_{4}$ at $\mathrm{pH}=1.4$, then the mixed system was agitated in water bath at $80^{\circ} \mathrm{C}$ until it became translucent sol. Several types of ceramics with nano- $\mathrm{TiO}_{2}$ thin film immobilized on glaze were prepared after 1, 3, 5 layers of humid film were, respectively, loaded and heated at $550^{\circ} \mathrm{C}$ for $2 \mathrm{~h}$ according to Section 2.2.

Figure 3(a) indicates that with the film layers added, the film's photocatalytic performance is improved. Layers' increasing means the amount and surface area of $\mathrm{TiO}_{2}$
TABle 3: The photocatalytic properties of $0.1 \mathrm{~mol} / \mathrm{L}$ sol film and $0.2 \mathrm{~mol} / \mathrm{L}$ sol film (150 min).

\begin{tabular}{lcccc}
\hline & 1 layer & 3 layers & 5 layers & 7 layers \\
\hline $\begin{array}{l}0.1 \mathrm{~mol} / \mathrm{L} \text { sol degradation } \\
\text { ratio }(\%)\end{array}$ & 5.4 & 12.8 & 17.6 & 18.9 \\
$\begin{array}{l}0.2 \mathrm{~mol} / \mathrm{L} \text { sol degradation } \\
\text { ratio }(\%)\end{array}$ & 8.1 & 9.5 & 1.6 & 6.5 \\
\hline
\end{tabular}

TABLE 4: Antibacterial property of the film with different layers.

\begin{tabular}{lccccc}
\hline Layers & Blank & 1 layer & 3 layers & 5 layers & 7 layers \\
\hline Antibacterial ratio (\%) & 35 & 48.5 & 76 & 71 & 72
\end{tabular}

loaded on films also increase. Figure 3(b) indicate that the film's photocatalytic performance is not improved with the film layers' adding as well as Figure 3(a). Its degradation rate reaches the maximum at 3 layers. It is because that loading superabundant $\mathrm{TiO}_{2}$ on the glaze would lead to reduction of the $\mathrm{TiO}_{2}$ surface area. Table 3 indicates that when the sol concentration is higher, the film with fewer layers would have better photocatalytic performance; when the sol concentration is lower, the film with more layers would have better photocatalytic performance.

According to the method stated at the beginning, but $1 \% \mathrm{AgNO}_{3}$ was added into $0.1 \mathrm{~mol} / \mathrm{L}$ sol to prepare $\mathrm{Ag} / \mathrm{TiO}_{2}$ films with 1, 3, 5 layers.

Table 4 indicates that antibacterial rate of the films is improved with the increasing of its layers which means that the amount of Ag embedding in films increases. It is also found that antibacterial rates of the film with 5 layers and 7 layers are not improved but lower than the one with 3 layers. It may because of superposition of the $\mathrm{TiO}_{2}$ 's network structure prevent the $\mathrm{Ag}^{+}$in the bottom films from dissolving into the bacteria solution.

3.3. Effect of Heating Temperature on the Photocatalytic and Antibacterial Performance. According to Section 2.1, 5\% nitric acid was used to peptize $0.1 \mathrm{~mol} / \mathrm{L} \mathrm{H}_{4} \mathrm{TiO}_{4}$ at $\mathrm{pH}=1.4$, then the mixed system was agitated in water bath at $80^{\circ} \mathrm{C}$ until it became translucent sol. Several types of ceramics with nano- $\mathrm{TiO}_{2}$ thin film immobilized on glaze were prepared after 3 layers of humid film was loaded and, respectively, heated at $350^{\circ} \mathrm{C}, 450^{\circ} \mathrm{C}, 550^{\circ} \mathrm{C}$, and $650^{\circ} \mathrm{C}$ for $2 \mathrm{~h}$ according to Section 2.2.

Before the thermal treatment, $\mathrm{TiO}_{2}$ of the film is amorphous. Figure 4 indicates that $\mathrm{TiO}_{2}$ of the film heated at $350^{\circ} \mathrm{C}$ begins turning to anatase at 2-Theta $=25.3^{\circ}$, the amorphous and anatase $\mathrm{TiO}_{2}$ coexist. According to the literature [11], $\mathrm{TiO}_{2}$ of the film heated at $500^{\circ} \mathrm{C}$ begins turning to rutile. It accords with the indication of Figure 4 that there is not rutile but anatase appearing in the film at $450^{\circ} \mathrm{C}$ and both of them coexist in the film at $550^{\circ} \mathrm{C}$. With the heating temperature reaches $650^{\circ} \mathrm{C}$, the amount of rutile $\mathrm{TiO}_{2}$ increases, and there is still some anatase $\mathrm{TiO}_{2}$ existing. According to the Scherre Formula [12], the average diameter of $\mathrm{TiO}_{2}$ crystal grain is $29.8 \mathrm{~nm}$, it is nano-film. 


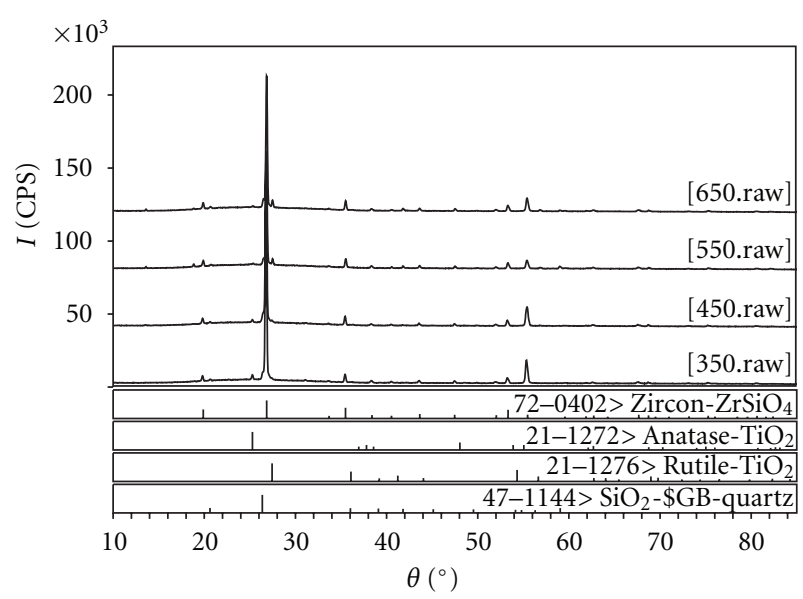

Figure 4: X-ray diffraction patterns of $\mathrm{TiO}_{2}$ thin film at different annealing temperature.

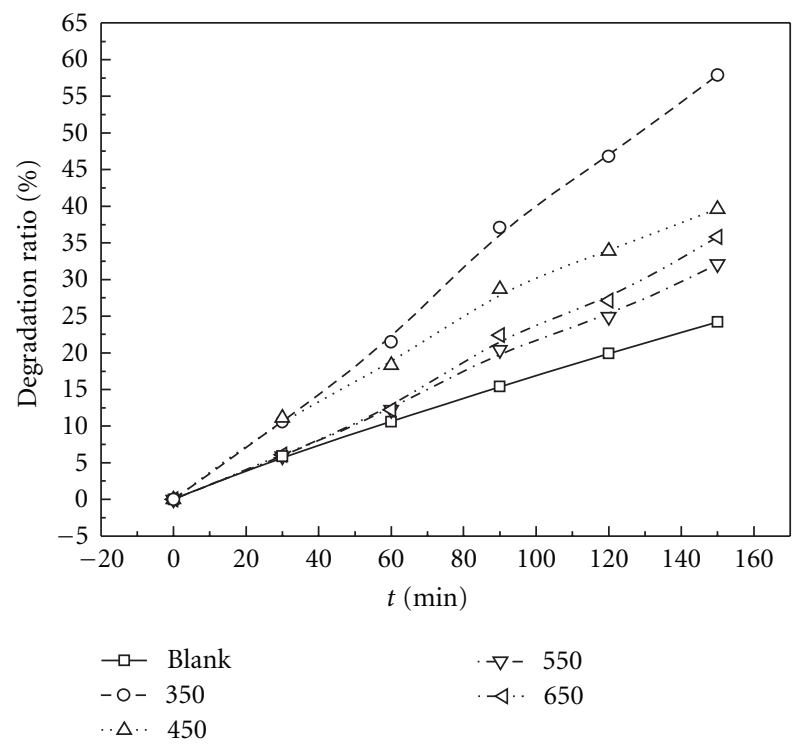

Figure 5: The different film annealing temperature to the photocatalytic degradation ratio of methyl orange.

Figure 5 indicates that the order of the film's degradation rate from max. to $\min$. is $350^{\circ} \mathrm{C}>450^{\circ} \mathrm{C}>650^{\circ} \mathrm{C}>550^{\circ} \mathrm{C}$. Generally speaking, anatase $\mathrm{TiO}_{2}$ has better more active photocatalytic performance than the rutile. With the heating temperature goes up, crystal grains of the film grow bigger, its surface area reduces and adsorption capability becomes weaker. Meanwhile the amount of the rutile increases. All of these leads to the decline of the photocatalytic performance. But it would be improved as if there is a amount of rutile exsiting in the film [11]. It is the reason for that the film heated at $650^{\circ} \mathrm{C}$ has higher degradation rate than the one heated at $550^{\circ} \mathrm{C}$. It may be the same reason for the film with the amorphous and anatase $\mathrm{TiO}_{2}$ coexisting has more active photocatalytic performance than the one with pure anatase $\mathrm{TiO}_{2}$.

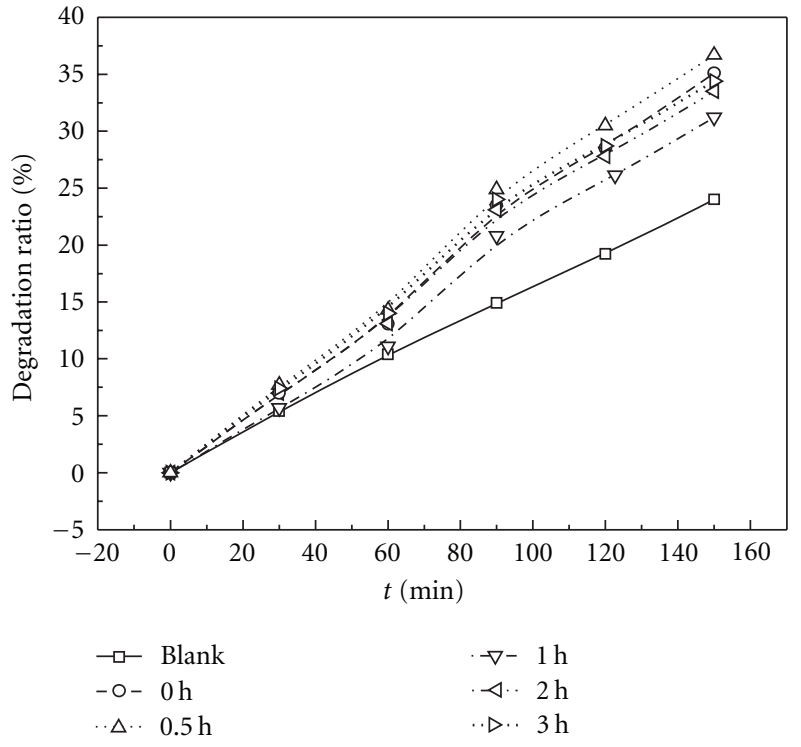

Figure 6: The different film annealing time to photocatalytic degradation ratio of methyl orange.

TABLe 5: Antibacterial property of the film at different annealing temperature.

\begin{tabular}{lcccccc}
\hline & Blank & $100^{\circ} \mathrm{C}$ & $350^{\circ} \mathrm{C}$ & $450^{\circ} \mathrm{C}$ & $550^{\circ} \mathrm{C}$ & $650^{\circ} \mathrm{C}$ \\
\hline Antibacterial ratio (\%) & 45 & 76.9 & 90.2 & 80 & 77.8 & 53.8 \\
\hline
\end{tabular}

According to the method stated at the beginning, but $1 \% \mathrm{AgNO}_{3}$ was added into the sol to prepare $\mathrm{Ag} / \mathrm{TiO}_{2}$ films heated at different temperature.

It could be found in Table 5 that the antibacterial rate of the film is going up with the heating temperature from $100^{\circ} \mathrm{C}$ to $350^{\circ} \mathrm{C}$, but the film heated at $100^{\circ} \mathrm{C}$ is not firmly attached on the glaze, it could fall off easily under the scraping of fingers. The antibacterial rate of the film is going down with the heating temperature from $350^{\circ} \mathrm{C}$ to $650^{\circ} \mathrm{C}$, it may because $\mathrm{AgNO}_{3}$ in the film turn into elementary substance or silver oxide which has lower solubility constant than $\mathrm{AgNO}_{3}$ and $\mathrm{Ag}_{2} \mathrm{SO}_{4}$ themselves.

3.4. Effect of Heating Time on the Photocatalytic and Antibacterial Performance. According to Section 2.1, 5\% nitric acid was used to peptize $0.1 \mathrm{~mol} / \mathrm{L} \mathrm{H}_{4} \mathrm{TiO}_{4}$ at $\mathrm{pH}=1.4$, then the mixed system was agitated in water bath at $80^{\circ} \mathrm{C}$ until it became translucent sol. Several types of ceramics with nano$\mathrm{TiO}_{2}$ thin film immobilized on glaze were prepared after 3 layers of humid film was loaded and, respectively, heated for $0 \mathrm{~h}, 0.5 \mathrm{~h}, 1 \mathrm{~h}, 2 \mathrm{~h}$, and $3 \mathrm{~h}$ at $550^{\circ} \mathrm{C}$ according to Section 2.2.

Figure 6 indicates that heating time has not marked effect on degradation rate of the films. With the heating time going up, degradation rate is increasing and reaches the max. at $0.5 \mathrm{~h}$, after that crystal grains of the film grow bigger with the increasing of heating time; besides that the amount of rutile is also increasing. All of these leads to poor photocatalytic performance. 


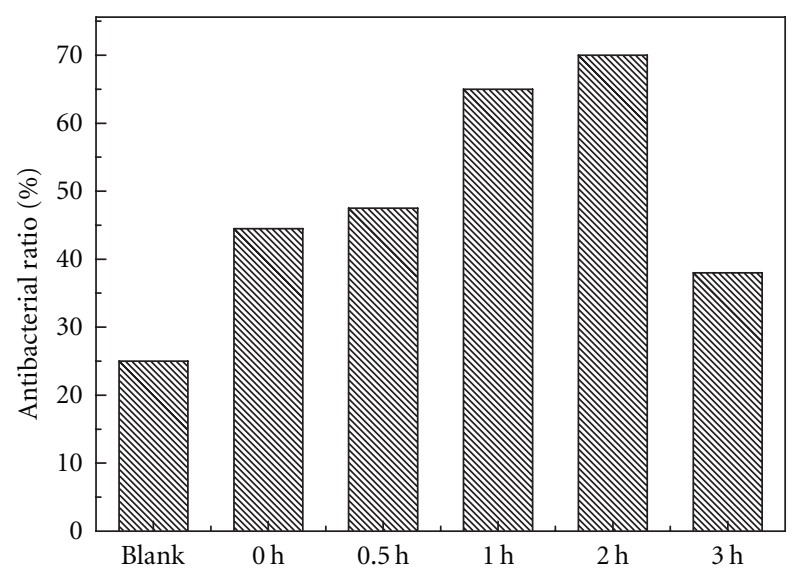

Figure 7: The Antibacterial property of the film at different annealing time.

According to the method stated at the beginning, but $1 \% \mathrm{AgNO}_{3}$ was added into the sol to prepare $\mathrm{Ag} / \mathrm{TiO}_{2}$ films heated for different hours.

Figure 7 indicates that antibacterial rate of the films is improved within the heating time $0 \mathrm{~h}$ to $2 \mathrm{~h}$ and is steady within $1 \mathrm{~h}$ to $2 \mathrm{~h}$, but when the heating time keep up increasing, the antibacterial rate goes down markedly. It may because more and more $\mathrm{AgNO}_{3}$ in the film gradually turn into elementary substance or silver oxide.

\section{Conclusion}

Embedding of $\mathrm{Ag}^{+}$helps to improve the photocatalytic and antibacterial performance, the optimum amount and type of $\mathrm{Ag}$ embedding in the film is $3 \% \mathrm{AgNO}_{3}$. With the film layers' adding, the film's photocatalytic and antibacterial performance are improved. The optimum layers of film is 3. To compromise the photocatalytic and antibacterial performance, $350^{\circ} \mathrm{C}$ is chosen as the optimum heating temperature. Heating time from $0 \mathrm{~h}$ to $3 \mathrm{~h}$ has not marked effect on degradation rate of the films. But heating time has concern with the film's antibacterial rate, the optimum heating time would be $2 \mathrm{~h}$.

\section{References}

[1] L. Xiangchuan, "Present situation and development of antibacterial ceramics material," Ceramics, vol. 28 , no. 5, pp. 13 $15,2000$.

[2] X.-P. Jiang, R. Heather, and H. Metiu, "Time dependent calculation of the absorption spectrum of a photodissociating system with two interacting excited electronic states," The Journal of Chemical Physics, vol. 90, no. 5, pp. 2555-2569, 1989.

[3] D. Xiangting, L. Guixia, Z. Weietal et al., "Nanocrystalline $\mathrm{SnO}_{2}$ synthesised by means of hydrothermal precipitation," Rare Metal Materials and Engineering, vol. 29, no. 3, pp. 197199, 2000.

[4] D. Xiangting, L. Guixia, S. Jing, J. Li, J. Liu, and G. Hong, "Preparation and properties of nanocrystalline $\mathrm{Yb}_{2} \mathrm{O}_{3}$," Rare
Metal Materials and Engineering, vol. 30, no. 1, pp. 73-76, 2001.

[5] Z. Lingke, Z. Haiwen, W. Hui, Z. Ming, S. Linlin, and $\mathrm{C}$ Yongjie, "Ceramics having antibacterial and germicidal function," Jiangsu Ceramics, vol. 34, no. 4, pp. 8-10, 2001.

[6] W. Jia, P. Bing, and C. Li-Yuan, "Study on the preparation of steady $\mathrm{Nano}_{-} \mathrm{TiO}_{2}$ water-so l," China Ceramic Industry, vol. 13, no. 6, pp. 45-50, 2006.

[7] Y. Zhang, L. Zhao, G. F. Yin, D. L. Zhou, and X. J. Xu, "Preparation and characterization of nanometer $\mathrm{TiO}_{2}$ film by sol method from $\mathrm{H}_{3} \mathrm{TiO}_{4}$," Chinese Journal of Inorganic Chemistry, vol. 20, no. 8, pp. 991-995, 2004.

[8] H. Li, G. Zhao, Q. Liu et al., "Influence of silicon doping and silicon vanadium co-doping on photocatalyst property of $\mathrm{TiO}_{2}$ thin films," Journal of the Chinese Ceramic Society, vol. 33, no. 6, pp. 784-788, 2005.

[9] W. Jin, J. Zongzhe, L. Jinsheng et al., "Stduy on the antibacterial test method for ceramics," Jiangsu Ceramics, vol. 34 , no. 4 , pp. 11-17, 2001.

[10] S. M. Attia, W. U. Guang-ming, M. A. Jian-hua et al., "Effect of heat treatment on properties of $\mathrm{TiO}_{2}$ films prepared with sol-gel method," Journal of Tongji University, vol. 1, no. 34, pp. 73-75, 2003.

[11] U. Balachandran and N. G. Eror, "Raman spectra of titanium dioxide," Journal of Solid State Chemistry, vol. 42, no. 3, pp. 276-282, 1982.

[12] C. H. Chen, E. M. Kelder, and J. Schoonman, "Electrostatic sol-spray deposition (ESSD) and characterisation of nanostructured $\mathrm{TiO}_{2}$ thin films," Thin Solid Films, vol. 342, no. 1-2, pp. 35-41, 1999. 

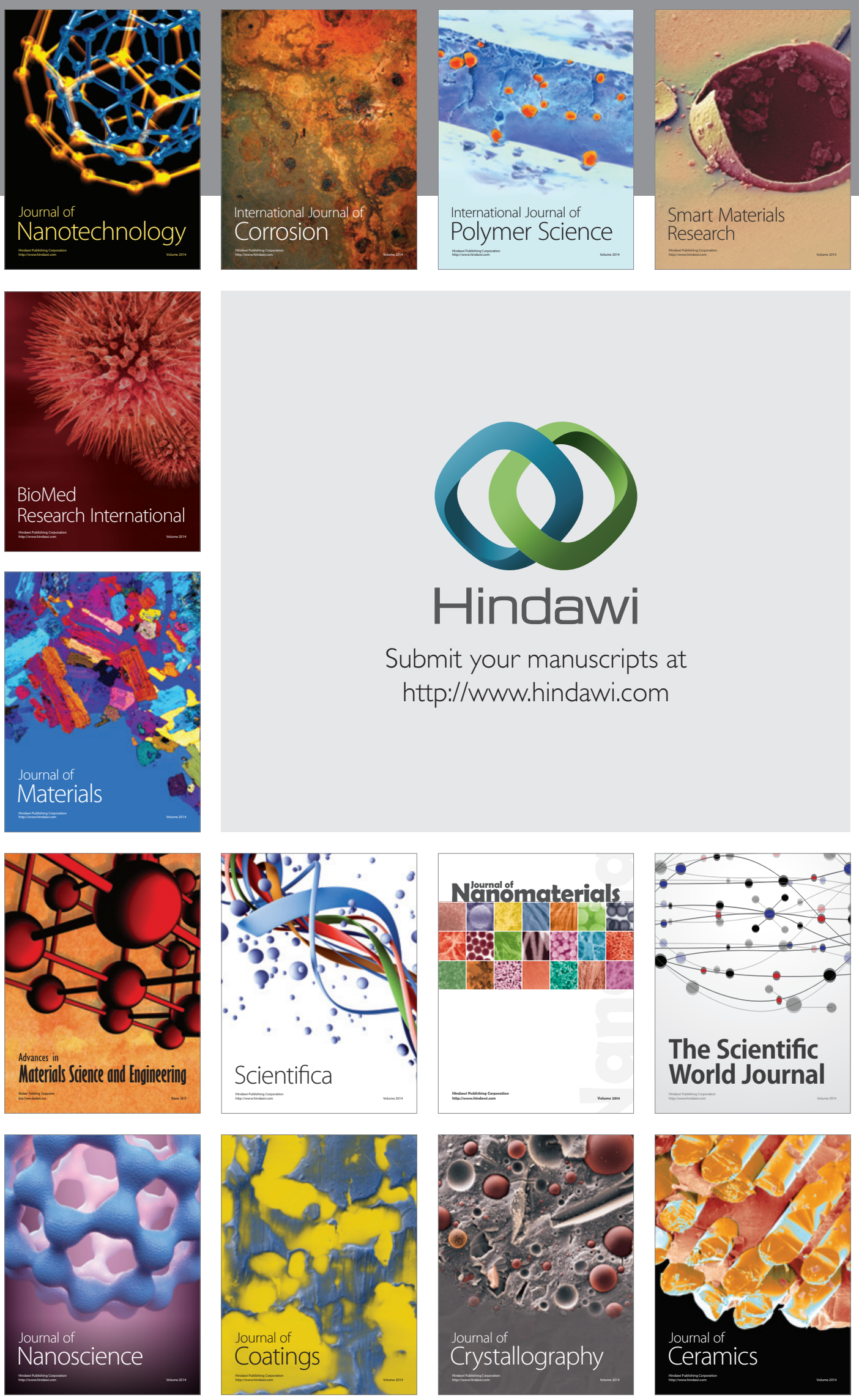

The Scientific World Journal

Submit your manuscripts at

http://www.hindawi.com

\section{World Journal}

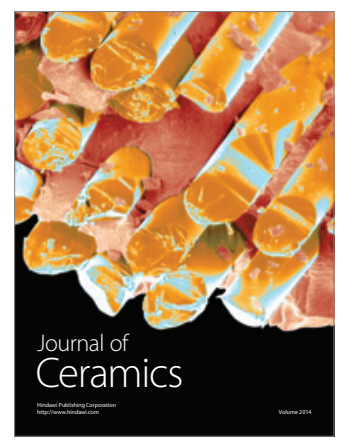

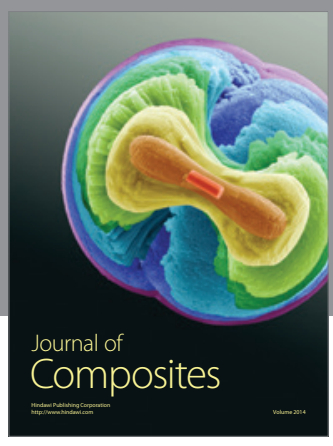
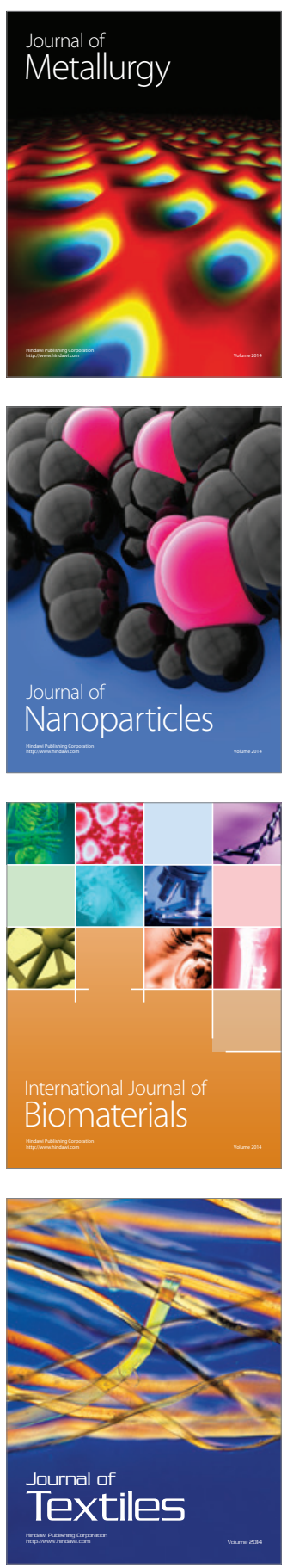